\title{
PENGARUH PENERAPAN MODEL ACTIVE LEARNING TIPE TEAM QUIZ TERHADAP HASIL BELAJAR KEWIRAUSAHAAN SISWA KELAS $X$ SEMESTER GENAP SMK KARTIKATAMA METRO TAHUN PELAJARAN 2014/2015
}

\author{
Ningrum \\ Pendidikan Ekonomi FKIP Universitas Muhammadiyah Metro \\ ningrum@yahoo.com
}

\begin{abstract}
Abstrak
Berdasarkan hasil belajar siswa kelas X di SMK Kartikatama Metro yang masih relatif rendah yang dapat dilihat dari kriteria ketuntasan minimum (KKM) dimana berdasarkan hasil observasi masih kurangnya pencapaian nilai kriteria ketuntasan minimum (KKM) yang telah ditetapkan oleh sekolah. Hasil belajar yang masih rendah ini juga disebabkan oleh metode pembelajaran yang diterapkan masih mengguanakan metode ceramah (metode konvensional). Metode -metode ini membentuk siswa salah satunya adalah model Active Learning tipe Team Quiz.

Hasil belajar yang belum tuntas berjumlah 15 siswa dengan presentase $62,5 \%$, dan yang mencapai ketuntasan belajar berjumlah 9 siswa dengan persentase 37,5\% Sedangkan nilai ketuntasan minimum (KKM) Kelas X SMK Kartikatama Metro pada pelajaran kewirausahaan adalah 75. Alternatif untuk meningkatkan hasil belajar siswa digunakan Model Active Learning Tipe Team Quiz, sehubungan dengan masalah tersebut maka rumusan masalahnya adalah "Apakah ada pengaruh Penerapan Model Active Learning Tipe Team Quiz Terhadap Hasil Belajar Kewirausahaan pada Siswa Kelas X Semester genap SMK Kartikatama Metro tahun pelajran 2014/2015" .

Adapun tujuan dalam penelitian ini adalah untuk mengetahui pengaruh penerapan Model Active Learning Tipe Team Quiz terhadap hasil belajar Kewirausahaan pada Siswa Kelas X Semester genap SMK Kartikatama Metro tahun pelajran 2014/2015”. Adapun kegunaannya adalah dengan mengetahui pengaruh penerapan Model Active Learning Tipe Team Quiz Terhadap Hasil Belajar Kewirausahaan pada Siswa Kelas X Semester genap SMK Kartikatama Metro tahun pelajaran 2014/2015", maka dapat digunakan sebagai acuan peneliti. Dan sebagai bahan informasi dalam usaha meningkatkan hasil belajar kewirausahaan di SMK Kartikatama Metro khususnya dan untuk menambah wawasan dibidang pendidikan bagi pembaca umumnya. Hipotesis dalam penelitian ini adalah."ada pengaruh positif Penerapan Model Active Learning Tipe Team Quiz, Terhadap Hasil Belajar kewirausahaan pada Siswa Kelas X Semester genap SMK Kartikatama Metro tahun pelajran 2014/2015”.

Setelah dianalisis data hasil penelitian dapat disimpulkan bahwa dari analisis perhitungan nilai $t_{\text {hitung }}$ dan $\mathrm{t}_{\text {tabel }}$, diketahui bahwa $\mathrm{t}_{\text {hitung }}>\mathrm{t}_{\text {tabel. }}$ dapat dilihat pada daftar $\mathrm{G}$, pada daftar signifikan $5 \%$ yaitu $9,10>1,72$. Dan pada taraf signifikan $1 \%$ yaitu $9,10>2,51$. Dengan demikian hipotesisnya berbunyi bahwa : ada pengaruh yang positif Penggunaan Model Active Learning Tipe team Quiz dapat meningkatkan hasil belajar kewirausahaan siswa kelas X.TKJ 1 semester genap SMK Kartikatama Metro pada pokok bahasan: mengeola konflik. Siswa yang dinyatakan tuntas dengan KKM (75) setelah treatment sebanyak 14 siswa atau sebesar $58,33 \%$ dan siswa yang dinyatakan belum tuntas sebanyak 10 siswa atau sebesar 41,67\%. oleh karena itu untuk meningkatkan hasil belajar siswa, guru dapat menerapkan penggunaan model Active Learning Tipe Team Quiz dalam pembelajaran yang diselenggarakan.
\end{abstract}

Kata Kunci : Model Active Learning Tipe Team Quiz, dan Hasil Belajar. 


\section{PENDAHULUAN}

Pendidikan adalah usaha sadar dan terencana untuk mewujudkan suasana belajar dan proses pembelajaran agar peserta didik secara aktif mengembangkan potensi dirinya untuk memiliki kekuatan spiritual, keagamaan, pengendalian diri, kepribadian, kecerdasan, akhlak mulia, serta keterampilan yang diperlukan dirinya, masyarakat, bangsa dan negara. Upaya meningkatkan sumber daya yang kompeten, maka mutu pendidikan harus lebih di tingkatkan. Sejalan dengan tuntutan tersebut, tugas pendidik tidak hanya sebatas pada ilmu pengatahuan dan teknologi semata tetap bertugas pula menanamkan nilai-nilai baru yang dituntut oleh perkembangan ilmu pengetahuan dan teknologi pada diri anak didik. Oleh karna itu, setiap yang terlibat dalam proses pendidikan harus mengerti dan memahami hakekat dari pendidikan yaitu membentuk manusia Indonesia yang bertaqwa kepada Tuhan Yang Maha Esa , memiliki pengetahuan dan ketrampilan, sehat jasmani dan rohani, berkepribadian mantap dan mandiri serta memiliki rasa tanggung jawab bagi kemajuan bangsanya.

Dapat diambil sebuah kesimpulan bahwa pendidikan memegang peranan penting dalam perkembangan bangsa dan negara. Pendidikan yang mampu memfasilitasi perkembangan bangsa salah satu diantaranya adalah pendidikan yang bermutu. Pendidikan yang bermutu sendiri sangat ditentukan oleh penyelenggaraan proses pembelajaran dan memberdayakan siswa serta berorientasi pada siswa. Salah satu aspek terpenting dalam kegiatan proses pembelajaran adalah guru. Sebagai tenaga pendidik, guru juga dituntut memiliki kemampuan dan juga harus menggunakan metode pembelajaran yang sesuaidengan karakteristik siswanya. Proses pembelajaran adalah suatu kontak sosial antara seorang guru dengan siswa untuk mencapai tujuan pembelajaran. Diharapkan siswa dapat berperan aktif, inovatif, kreatif, serta efektif dalam mengikuti proses pembelajaran sehingga pembelajaran menjadi menyenangkan (Team Quiz).

Sekolah kejuruan memiliki mata diklat produktif yang memerlukan penerapan teori dan pengaplikasian keterampilan secara lebih intensif. Aktivitas siswa di sekolah kejuruan dirancang lebih beragam, tidak hanya sebatas mencatat materi dan mendengarkan penjelasan dari guru. Siswa diarahkan untuk dapat memahami materi dan juga mahir dalam mengaplikasikan materi dengan keterampilan tertentu. Hal ini sebagai bekal siswa, dimana di sekolah kejuruan terdapat progarm job training dan siswa disiapkan untuk langsung terjun di dunia kerja ketika lulus. Guru dan siswa perlu menyamakan persepsi akan tujuan 
pembelajaran yang akan dicapai sehingga tidak hanya guru yang berupaya mendorong siswa untuk aktif namun siswa juga memiliki insiatif untuk aktif. Apabila siswa telah menyadari manfaat dan tujuan dari aktivitas pembelajaran, maka siswa akan memiliki insiatif dan mau terlibat dalam aktivitas pembelajaran yang lebih beragam seperti praktikum, diskusi, pengamatan, memecahkan masalah dan sebagainya. Komunikasi interaktif yang lancar antara guru dan siswa akan membuat suasana kelas menjadi kondusif sehingga pembelajaran dapat berjalan dengan lancar dan hasil pembelajaran maksimal.Berdasarkan observasi peneliti, Proses Pembelajaran yang berlangsung di sekolah SMK KartikatamaMetro dalam meningkatkan mutu pendidikan telah melakukan berbagai upaya yang dilakukan antara lain dalam proses pembelajaran,peran guru dalam megikuti pelatihan-pelatihan serta setiap guru wajib membuat perangkat pembelajaran seperti progam tahunan, program semester, silabus, rencana pelaksanaan pembelajaran. Namun dengan demikian hasil belajar Kewirausahaan masih cenderung rendah dengan ditandai banyak nya siswa yang belum mencapai kriteria ketuntasan minimal (KKM), dimana $\mathrm{KKM}$ mata pelajaran Kewirausahaan adalah 75 . Kondisi tersebut juga terjadi pada Kelas X.TKJ 1 di SMK Kartikatama Metro pada pelajaran Kewirausahaan semua siswa mendapatkan beban materi yang sesuai dengan tingkatan kelasnya. Namun ternyata, masih banyak siswa yang hasil belajarnya kurang memuaskan jika didasarkan nilai KKMnya 75.

Berdasarkan keadaan diatas, penulis mencoba menggunakan model Active Learning tipe Team Quiz karena model ini dipandang relevan dengan masalah diatas dalam rangka meminimalisir permasalahan tersebut dan untuk meningkatkan hasil belajar siswa. Dimana aktivitas belajar juga dapat menunjukkan bagaimana aktivitas seorang siswa, semakin tinggi tingkat keatifan siswa maka siswa tersebut mempunyai aktivitas belajar yang baik. Sebaliknya, semakin rendah tingkat keaktifan siswa menunjukkan bakwa aktivitas belajarnya masih rendah.

Data hasil prasurvei yang telah dilakukan di SMK Kartikatama Metro kelas X TKJ.1 Semester Ganjil tahun pelajaran 2014/2015 diperoleh data hasil belajar Kewirausahaan sebagai berikut: 
Tabel 1. Data hasil mid semester ganjil bidang studi Kewirausahaan siswa Semester ganjil kelas X.TKJ 1 SMK KartikatamaMetro Tahun Pelajaran 2014/2015

\begin{tabular}{|l|l|l|c|c|}
\hline No & Nilai & Keterangan & Jumlah & Persentase \\
\hline 1. & $\geq 75$ & Tuntas & 9 & $37,5 \%$ \\
\hline 2. & $<75$ & BelumTuntas & 15 & $62,5 \%$ \\
\hline \multicolumn{2}{|l|}{ Jumlah } & - & 24 & $100 \%$ \\
\hline
\end{tabular}

Sumber : Hasil Pra Survei Diambil dari daftar mid semester ganjil bidang studi Kewirausahaan kelas X.TKJ 1 SMK Kartikatama Metro Tahun Pelajaran 2014/2015

Berdasarkan tabel di atas, dapat dilihat bahwa terdapat 9 siswa yang mendapat nilai $\geq 75$ dengan kategori tuntas pada mata pelajaran Kewirausahaan dengan presentase $37,5 \%$ dan 15 siswa yang mendapat nilai $<75$ dengan kategori belum tuntas dengan presentase $62,5 \%$. Dengan demikian, dari data di atas dapat disimpulkan bahwa masih banyak hasil belajar Kewirausahaan yang belum tuntas pada siswa kelas X.TKJ 1semester ganjil SMK Kartikatama Metro.

Permasalahan diatas menunjukkan bahwa masih banyaknya siswa yang belum tuntas pada hasil belajar Kewirausahaan, maka perlu dikembangkan suatu model pembelajaran yang mampu melibatkan peran siswa secara menyeluruh sehingga kegiatan belajar mengajar tidak hanya didominasi oleh siswa-siswa tertentu saja, yaitu dengan menggunakan model pembelajaran Active Learning tipe Team Quiz dapat digunakan untuk membantu siwa memperoleh pengetahuan, keterampilan, dan sikap secara aktif. Tipe
Team Quiz mengajak siswa melakukan diskusi, bertanya, menjawab pertanyaan, memberi arahan, mengemukakan pendapat, dan menyampaikan informasi dengan cara bekerjasama bersama timnya. Dengan demikian siswa akan lebih terbuka dan percaya diri karena mendapat dukungan dari rekan timnya.

Berdasarkan tabel di atas, dapat dilihat bahwa terdapat 9 siswa yang mendapat nilai $\geq 75$ dengan kategori tuntas pada mata pelajaran Kewirausahaan dengan presentase $37,5 \%$ dan 15 siswa yang mendapat nilai $<75$ dengan kategori belum tuntas dengan presentase $62,5 \%$. Sedangkan kriteria ketuntasan minimal (KKM) pada mata pelajaran kewirausahaan adalah 75 . Berdasarkan uraian di atas, dengan menerapkan Model Active Learnig tipe Team Quiz diharapkan akan dapat diterapkan untuk membantu siswa lebih aktif dan kreatif dalam proses belajar sehingga akan tercapainya suatu hasil belajar yang maksimal. 
Berdasarkan latar belakang keadaan tersebut diatas ditemukan permasalahan: "Bahwa hasil belajar mata pelajaran kewirausahaan kelas $\mathrm{X}$ TKJ.1 semester ganjil SMK Kartikatama Metro Tahun pelajaran 2014/2015 masih banyak yang belum tuntas"

Berdasarkan permasalahan tersebut maka penulis merumuskan masalah sebagai berikut: "Apakah ada pengaruh penerapan model Active Learning tipe Quiz Team terhadap hasil belajar siswa Kewirausahaan siswa kelas $\mathrm{X}$ semester genap SMK Kartikatama Metro Tahun Pelajaran 2014/2015”?

Berdasarkan rumusan masalah tersebut, maka dalam penelitian ini penulis mengangkat judul: "PENGARUH PENERAPAN MODEL ACTIVE LEARNING TIPE TEAM QUIZ TERHADAP HASIL BELAJAR KEWIRAUSAHAAN SISWA KELAS X SEMESTER GENAP SMK KARTIKATAMA METRO TAHUN PELAJARAN 2014/2015”.

Berdasarkan rumusan masalah di atas yang menjadi tujuan penelitian ini adalah "Untuk mengetahui pengaruh penggunaan model Active Learning tipe Team Quiz terhadap hasil belajar siswa Kewirausahaan siswa kelas $\mathrm{X}$ semester Genap SMK KartikatamaMetro Tahun Pelajaran 2014/2015".
Adapun kegunaan yang diharapkan dari hasil penelitian ini adalah:

1. Dengan mengetahui pengaruh penerapan model Active Learning tipe Team Quiz terhadap hasil belajar Kewirausahaan, maka dapat menambah pengetahuan dan wawasan bagi penulis dalam melakukan penelitian.

2. Untuk memenuhi salah satu syarat dalam penyusunan skripsi dan penyelesaian studi di Universitas Muhammadiyah Metro.

Definisi istilah merupakan gambaran variabel untuk lebih jelas. Sedangkan definisi operasional variabel adalah rumusan yang lebih tegas dari variabel yang akan diteliti. Rumusan ini didasarkan atas konsep teori yang disebut juga dengan landasan teori. Dalam penelitian ini akan dijelaskan kategori indikator-indikator operasional yang akan diteliti sebagai pedoman dalam penelitian yang akan dilakukan.

\section{KAJIAN PUSTAKA}

\section{Model Active Learning tipe Team Quiz}

Model Active Learning tipe Team Quiz, dimana cara yang digunakan guru dalam proseslpembelajaran dengan prosedur siswa dibentuk dalam kelompok dengan masingmasing anggota mempunyai tanggung jawab yang sama atas keberhasilan kelompok nya memahami materi dan 
menjawab soal. Tipe Team Quiz ini dapat meningkatkan kemampuan peserta didik terhadap apa yang mereka pelajari serta, menghidupkan suasana dan mengaktifkan siswa untuk bertanya ataupun menjawab melalui cara yang menyenangkan. Langkah- langkah Tipe Tean Quiz ini adalah:

a) Pemilihan Topik

b) Pembagian Tim

c) Penyajian Materi

d) Persiapantim A menjawab, tim B dan C memeriksacatatan

e) Melemparkan pertanyaan ke Tim lainnya.

f) Mengarahkan pertanyaan dan memberikan jawaban

g) Menunjuk pemandu kuis untuk segmen tim berikutnya

h) Melanjutkan segmen Berikutnya

\section{Hasil Belajar}

Hasil Belajar adalah sesuatu yang dicapai atau diperoleh siswa baik perubahan tingkahlaku maupun skor atau prestasi belajar yang tinggi berkat adanya usaha dan fikiran, yang manahal tersebut dinyatakan dalam bentuk penguasaan materi dan kecakapan dasar dalam proses pembelajaran. Kemudian disertai keterampilan untuk mampu mengaplikasikan hasil belajar siswa dengan $K K M \geq 75$.

\section{Kerangka Berpikir dan Paradigma}

\section{a. Kerangka Berpikir}

1) Kerangka Anggapan Dasar

Kerangka anggapan dasar merupakan gambaran umum tentang variabel penelitian serta faktor-faktor yang mempengaruhi dan terikat didalamnya.

2) Kerangka Analitik

Kerangka Analitik merupakan pola untuk mengetahi inidkator-indikator yang paling fundamental yang dapat mempengaruhi hasil belajar. Menurut Sugiyono (2008:35) kerangka analitik adalah "pemikiran untuk mengetahi faktor-faktor yang paling dominan dan dapat mempengaruhi hasil belajar".

\section{b. Paradigma Penelitian}

Paradigma adalah gambaran atau skema tentang gejala atau peristiwa tentang pokok-pokok penelitian dan hubungan satu sama lain. Menurut Sugiyono (2011:66) Paradigma diartikan sebagai pola pikir yang menunjukkan hubungan antara variabel yang akan diteliti dengan sekaligus mencerminkan jenis dan jumlah rumusan masalah yang perlu dijawab melalui 
penelitian, teori yang digunakan untuk merumuskan hipotesis, dan teknik analisis statistik yang akan digunakan.

Berdasarkan pengertian diatas dapat disimpulkan bahwa paradigma merupakan suatu pola pikir mengenai hubungan antar variabel yang diteliti dan jawaban atas rumusan masalah serta menjelaskan teknik statistik yang akan digunakan dalam penelitian.

\section{METODE PENELITIAN}

Penelitian ini merupakan penelitian yang bersifat pengaruh atau eksperimen. Yang menjadi pengaruh antara lain variabel bebas dan variabel terikat. Dalam penelitian ini mencari bagaimana pengaruh model Active Learning tipe Team Quiz terhadap hasil belajar kewirausahaan dengan menggunakan metode eksperimen sebagai metode dalam pengumpulan data. Variabel dalam penelitian ini dikelompokkan menjadi dua, yaitu: variabel bebas adalah variabel yang mempengaruhi atau yang menjadi sebab perubahannya atau timbulnya variabel dependen (terikat). Variabel terikat (dependent variabel) merupakan variabel yang dipengaruhi atau yang menjadi akibat, karena adanyavariabel bebas.

Dalam penelitian yang di pengaruhi oleh variabel bebas yaitu model Active
Learning tipe Team Quiz (X) Variabel terikat dalam penelitian ini adalah Hasil belajar kewirausahaan (Y). Langkah langkah penelitian tahap persiapan penelitian menerapkan sampel sebgaia kelompok yang akan diberikan (treatmen), menyiapkan bahan atau alat yang digunakan dalam melaksanakan perlakuan (treatment) model Active Learning tipe Team Quiz. Menjelaskan konsep pembelajaran atau materi pembelajaran, menjelaskan langkah-langkah pembelajran dengan menggunakan model Active Learning tipe Team Quiz, siswa dibagi menjadi 3 tim A, B dan C. Kemudian penyajikan Materi, materi yang telah selsai disampaiakan merintahkan masing-masing tim untuk menyiapkan pertanyaan dimulai dari tim A, sementara tim B menyiapkan jawaban, jika tim B tidak dapat menjawab melemparkan pertanyaan ke Tim C dan seterusnya tim mengarahkan pertanyaan dan memberikan jawaban. Jika tanya jawab selesai, lanjutkan pelajaran kedua dan tunjuk kelompok B untuk menjadi kelompok penanya. Lakukan seperti proses untuk kelompok A. Setelah kelompok B selesai dengan pertanyaannya, lanjutkan penyampaian materi pelajaran ketiga dan tunjuk kelompok C sebagai kelompok penanya. Akhiri pelajaran dengan menyimpulkan tanya jawab dan jelaskan sekiranya ada pemahaman siswa yang keliru. Melakukan pos-test untuk 
mengetahui sejauh mana materi yang sudah diserap oleh peserta didik.

\section{Populasi dan sampel}

a. Populasi

Populasi adalah sekumpulan orang yang akan dijadikan objek pengamatan dalam penelitian. Menurut Arikunto (2006:130) populasi adalah "keseluruhan subjek penelitian". Dalam penelitian ini yang menjadi populasi adalah seluruh kelas X di SMK Kartikatama Metro semester genap Tahun Pelajaran 2014/2015 yang berjumlah 138 siswa, terdiri dari 5 kelas yaitu Kelas X AK 1 berjumlah 30 siswa, Kelas X AK 2 berjumlah 30 siswa, Kelas $\mathrm{X}$ TKJ 1 berjumlah 24 siswa, Kelas X TKJ 2 berjumlah 21 siswa, Kelas X OTO berjumlah 33 siswa.

b. Sampel

Sampel adalah bagian dari keseluran populasi yang diambil atau dipilih untuk mewakili populasi tersebut. Menurut Sugiyono (2011:81) Sampel adalah bagian dari jumlah dan karakteristik yang dimiliki oleh populasi tersebut. Bila populasi besar, dan peneliti tidak mungkin mempelajari semua yang ada pada populasi, misalnya karena keterbatasan dana, tenaga dan waktu, maka peneliti dapat menggunakan sampel yang diambil dari populasi itu. Pengambilan sampel disini menggunakan sampling purposive. Sampel dalam penelitian ini adalah kelas TKJ.1 yang berjumlah 24 siswa sebagai kelas eksperimen.

c. Teknik Pengumpulan Data

Teknik pengumpulan data pada penelitian ini melalui:
a) Observasi
b) Wawancara
c) Dokumentasi
d) Eksperimen
e) Tes

\section{PEMBAHASAN HASIL PENELITIAN}

Pengaruh penggunaan model active learning tipe Team Quiz yang dilakukan selama penelitian untuk mendapatkan data tentang hasil belajar kewirausahaan pada siswa hasli uji pre test dan post test ditetapkan dengan data primer yang diambil dari nilai hasil uji pre test dan post test ini selanjutnya dianalisis untuk memperoleh gambaran atau keadaan awal hasil belajar kewirausahaan sebelum diberi perlakuan atau treatmen model active learning tipe Team Quiz. Rekapitulasi hasil pre test dengan kategori tuntas berjumlah 5 siswa dengan presentase $20,83 \%$ dan kategori belum tuntas berjumlah 19 siswa dengan presentase $79,17 \%$. Dari data tersebut terlihat banyaknya datan (n) ada 24 siswa dengan nilai terbesar adalah 85 dan nilai terendah adalah 45 sehingga rentang $(\mathrm{R})$ dari tabel tersebut adalah 40 banyak kelas interval (K) Banyak Skor $(\mathrm{n})=24$ Skor Terbesar : 85 dan skor terkecil : 45 Rentang 
$(\mathrm{R})=(85-45)=40$ Banyaknya kelas interval $(\mathrm{K})=1+3,3 \log 24=1+3,3$ $(1,380)=5,554$ (dibulatkan) $=6$ Panjang kelas interval $=7$ setelah itu dibuat tabel dihitung nilai $\quad \overline{\mathrm{X}}=\frac{\Sigma f_{i} x_{i}}{\Sigma f_{i}}=$ $S_{t}^{2}=\frac{n \Sigma f_{i}\left(x_{i}^{2}\right)-\left(\sum f_{i} x_{i}\right)^{2}}{n(n-1)}$ dan untuk hasil belajar kewirausahaan yang didapatkan dari hasil rekapitulasi hasil postestnya dengan kategori tuntas berjumlah 14 dengan presentase $58,33 \%$ dan hasil belajaryang belum tuntas berjumlah 10 dengan presentase $41,67 \%$ bahwa banyknya data (n) adalah 24 siswa dengan nilai tes terbesar 90 dan nilai terendah adalah 50 sehingga rentang (R) dari data tersebut adalah 40 banyak kelas interval $(\mathrm{K})$ dengan formula berikut: $K=1+(3,3 \log n)=1+(3,3 \log$ 24) $=1+(1,380)=1+4,554=5,554$ (dibulatkan) 6 Panjang kelas interval (P) adalah:

$$
\mathrm{P}=\frac{R}{K}=\frac{40}{6}=6,67=7 \text { Ditentukan }
$$
dengan membuat tabel distribusi frekuensi.

Analisis Data dan Pengujian Hipotesis Untuk menganalisis data sebagai objek dari penelitian adalah nilai hasil pretest dan Postest Kewirausahaan diberikan pada siswa untuk mengetahui keadaan awal hasil belajar kewirausahaan sebelum diberikan perlakuan atau Treatment, pada pokok bahasan Mengelola Konflik. Sedangkan nilai yang digunakan dalam perhitungan untuk menguji hippotesis adalah nilai yang telah diperoleh hasil pengujian $\mathrm{Uji}$ Normalitas Rumus hipotesis: $\mathrm{H}_{0}=$ Sampel diambil dari populasi yang berdistribusi normal. $\mathrm{H}_{1}=$ Sampel yang diambil dari populasi yang tidak berdistribusi normal Hasil Evaluasi Pre-test Kewirausahaan siswa kelas X TKJ.1 SMK Kartikatama Metro. Berdasarkan pendiskripsian data hasil Pretest penelitian bahwasannya nilai mean dari data adalah 63,75 dan simpangan bakunya 10,5758. Selanjutnya hadil uji coba postest bahwasannya nilai mean dari data adalah 72,25 dan simpangan bakunya adalah 10,1650 setelah diketahui nilai mean dari data dan simpangan bakunya dilanjutkan dengan menghitung frekuensi yang diharapkan $\left(\mathrm{E}_{1}\right)$ dengan langkahlangkah sebagi berikut: Menentukan kelas batas bawah kelas (x) yaitu ujung kelas interval dikurangi 0,5 dan ujung kelas atas ditambah 0,5 . Mennentukan $\mathrm{Z}$ untuk batas kelas dengan rumus : $\mathrm{Z}_{1}=\frac{x-x}{s}$ untuk tiaptipa nilai z jika nilai positif maka $F(z)=0,5$ + nilai peluang jika nilai $\mathrm{Z}$ negatif maka $\mathrm{F}(\mathrm{z})=0,5$ - nilai peluang dan untuk menentukan luas tiap-tiap kelas interval $\left(\mathrm{L}_{1}\right)$, mencarinya $\mathrm{Z}$ atas dan $\mathrm{Z}$ bawah dilihat dari dftar F, menentukan frekuensi yang diharapkan $\left(\mathrm{E}_{1}\right)$ yaitu hasil kali luas tiap interval dengan banyak data atau rumus $\mathrm{E}_{1}$ $=\mathrm{L}_{1}$ x n Selanjutnya untuk menentukan $c h i$ 
kuadrat hitung sebgai berikut: Dengan kriteria uji, tolak $\mathrm{H}_{\mathrm{o}}$ jika: $x^{2}{ }_{h i t} \geq x_{(1-\alpha)(k-3)}^{2}$ dalam hal lain hipotesis diterima. Berdasarkan tabel dapat diketahui banyaknya kelas interval adalah 6, maka $x_{(1-\alpha)(k-3)}^{2}$ adalah 6-3=3. Dengan menggunakan taraf nyata $(\alpha)=0,05$ atau $(\alpha)=0,01$ harga tersebut dapat dilihat pada daftar H. Ternyata untuk taraf nyata 0,05 ataupun 0,01 didapat bahwa $X_{h i t}^{2}<X_{d a f}^{2}$ untuk taraf nyata 0,05 adalah $2,58<7,81$ dan untuk taraf nyata 0,01 adalah 2,58< 11,3. Dari kriteria di atas dapat disimpulkan bahwa $H_{o}$ diterima. Hal ini menunjukan bahwa distribusi frekuensi nilai pre-test pada siswa kelompok eksperimen berdistribusi normal. Hal ini menunjukkan bahwa distribusi frekuensi nilai pst test pada siswa kelas eksperimen mengikuti distribusi normal. Dalam pengujian hipotesis kerja untuk mengetahui pengaruh penggunaan model Active Learning tipe Team Quiz terhadap hasil beljar kewirausahaan. Maka data dianalisis terlebih dahulu menggunakan rumus regresi linier sederhana. Analisis untuk mengetahui hubungan dua variabel, maka data yang telah dikumpulkan analisis dengan menggunakan tabel s, dapat diketahui bahwa variabel $\mathrm{X}$ (Uji pretest) siswa yang tuntas hasil belajar kewirausahaan berjumlah 19 siswa dari 24 siswa dan pada variabel Y (uji post test) siswa yang tuntas berjumlah 14 siswa sedangkan yang belum tuntas berjumlah 10 dari 24 siswa. Berdasarkan nilai-nilai tersebut diatas maka dihitung Regresi Linier Sederhana menurut Sudjana (2005:312) dengan rumus $\hat{\mathbf{Y}}=\mathbf{a}+\mathbf{b X}$ Kemudian untuk menguji apakah ada pengaruh penerapan model Active Learning tipe Team Quiz terhadap hasil belajar Kewirausahaan dibuktikan dengan menggunakan $t_{\text {hitung dapat dihitung dengan }}$ cara sebagai berikut: $\mathrm{t}=\frac{b}{S b}$ Dalam penelitian ini setelah siswa mendapatkan Treatment atau perlakuan model Active Learning tipe team Quiz hasil belajar mengalami peningkatan dilihat dari perbandingan pada evaluasi pre test dan post test, yaitu siswa yang mencapai kriteria ketuntasan minimal pada evaluasi pretest adalah 20,83 atau 5 siswa dari 24 siswa, sedangkan siswa yang mencapai kriteria ketuntasan minimal pada evaluasi posttest adalah 58,33 atau 14 siswa, dari total keseluruhan siswa sebanyak 24 siswa. Secara keseluruhan bahwa setelah siswa mendaoatkan treatment perlakuan model Active Learning tipe Team Quiz hasil belajar Kewirausahaan mengalami peningkatan. 


\section{KESIMPULAN}

Berdasarkan penelitian yang telah dilakukan oleh penulis, maka dapat disimpulkan bahwa hasil pengumpulan data yang dikumpulkan dari 24 siswa yang diberikan perlakuan (treatment) dengan model Active learning tipe Team Quiz, hasil belajar Kewirausahaan siswa yang masuk dalam kategori tuntas sebanyak 58,33\% yaitu 14 siswa dan yang belum tuntas 41,67\% yaitu 10 siswa.

Pada pengujian dengan menggunakan rumus Regresi Linear Sederhana diperoleh $\alpha=22,8804, b=0,7732$ sehingga demikian $\hat{Y}=a+b X$ adalah $\mathrm{Y}=$ $22,8804+0,7732 X$ kemudian dari hasil analisis diperoleh bahwa ada pengaruh yang positif model Active learning tipe Team Quiz terhadap hasil belajar Kewirausahaan siswa kelas X.TKJ 1 SMK Kartikatama Metro. Hal ini dibuktikan dengan perhitungan analisis bahwa $t_{\text {hitung }}>t_{\text {tab }}$ dan terlihat pada taraf signifikan 5\% adalah $9,10>1,72$ dan pada taraf signifikan $1 \%$ yaitu $9,10>2,51$ yang dapat dilihat pada daftar $\mathrm{G}$ statistik, dengan demikian maka hipotesis diterima. Jadi “ada pengaruh yang positif penggunaan model Active Learning tipe Team Quiz terhadap hasil belajar Kewirausahaan siswa kelas X.TKJ1 semester genap SMK Kartikatama Metro tahun pelajaran 2014/2015.

\section{DAFTAR PUSTAKA}

Arikunto, Suharsimi. 2006. posedur penelitian suatu pendekatan Praktek. Jakarta: Rineka Cipta.

2013. posedur penelitian suatu pendekatan Praktek. Jakarta: Rineka Cipta.

Sudjana. 2005. Metoda Statistika Edisi Revisi 6. Bandung: Tarsito.

Sugiyono. 2008. Metode Penelitian Kuantitatif Kualitatif Dan $R \& B$. Bandung: CV. ALFABET

2011. Metode Pendekatan Pendidikan Pendekatan Kualitatif Kuantitatif dan $R \& D$.Bandung: Alfabeta. 